\title{
Kent İçi Raylı Sistem Yatırım Ölçütlerinin Üzerine Bir Araştırma:
} Erzincan Kent İçi Raylı Sistem Örneği

\section{Dr. Hayri Ulvi ${ }^{1^{*}}$ \\ Furkan Akdemir ${ }^{2}$}

Geliş tarihi: 11.04 .2019

Kabul tarihi: 24.04.2019

\section{Atıf bilgisi:}

Uluslararası Bilimsel

Araştırmalar Dergisi (IBAD)

Cilt: $4 \quad$ Sayı: 2

Sayfa: 333-354 Yil: 2019

Dönem: Yaz

This article was checked by Turnitin Similarity Index 15\%

1 Gazi Üniversitesi, Türkiye, hayriulvi@gazi.edu.tr,

ORCID ID 0000-0003-2988-6215

2 Gazi Üniversitesi KUTEM, Türkiye, akdemirfurkan10@gmail.com, ORCID ID 0000-0003-0964-338X

* Sorumlu yazar

\section{$\ddot{O} \mathbf{Z}$}

Günümüzde birçok kent, ulaşım sisteminde sağladığg çeșitli faydalardan dolayı kent içi raylı sistemleri, kalkınmayı sağlayan sürdürülebilir nitelikte toplu ulaşım hizmet türü olarak değerlendirmektedir. Kent içi raylı sistemlerin kentsel ulaşım sistemi içinde yer alması, yerel yönetimlerin yatırım programları aracılığıyla gerçekleşmektedir. Türkiye'de tüm ölçeklerde kent içi raylı sistemlerin yatırımı için konvansiyonel olarak yolcu sayısı ölçütü etkili olarak kullanılmaktadır. Sadece yolcu sayısına bağlı olarak yatırım değerlendirme yaklaşımları, kent içi raylı sistemlerin yaygınlaşmamasına neden olmakta ve dolayısı ile ülke kalkınmasının önüne geçmektedir. Bu çalışmada kalkınma süreci devam eden orta ölçekli kentlere odaklanılarak kent içi raylı sistem yatırımlarının faydasına dayalı yeni yatırım ölçütleri konjoint analizi ile belirlenmektedir. Orta ölçekli kentlerin gelişim eğiliminde etkili olan temel unsurlardan biriside ulaşım kavramıdır. Bir toplu taşıma hizmeti olarak kent içi raylı sistemler sağladığı faydalar ile gelişmekte olan kentlerin ilgi odağında yer almaktadır. Kullanılan konjoint analizi ile birlikte orta ölçekli kentlerde raylı sistem yatırımlarının modern gereklilikler açısından nasıl bir niteliğe sahip olmasi ifade edilmektedir.

Anahtar Kelimeler: Ulaşım, Kent İçi Raylı Sistem, Fizibilite, Konjoint Analizi. 


\section{A Research on Urban Rail System Investment Criteria: Erzincan Urban Rail System Example}

\section{Dr. Hayri Ulvi ${ }^{1^{*}}$ \\ Furkan Akdemir ${ }^{2}$}

First received: 11.04.2019

Accepted: 24.04.2019

\section{Citation:}

Journal of the International

Scientific Research (IBAD)

Volume: 4 Issue: 2

Pages: 333-354 Year: 2019

Session: Summer

This article was checked by Turnitin. Similarity Index 15\%

\footnotetext{
1 Gazi University, Turkey, hayriulvi@gazi.edu.tr

ORCID ID 0000-0003-2988-6215

2 Gazi University UTTAC, Türkive, akdemirfurkan10@gmail.com

ORCID ID 0000-0003-0964-338X
}

\section{* Corresponding Author}

\begin{abstract}
Today, many cities consider urban rail systems to be a sustainable public transportation service that provides development due to the various benefits provided in the transportation system. The involvement of urban rail systems within the urban transport system is realized through investment programs of local administrations. The number of passengers of all sizes as conventional for investment in urban rail system in Turkey is used as an effective measure. Depending on the number of passengers, investment evaluation approaches cause urban rail systems not to become widespread and thus prevent the development of the country. In this study, the new investment criteria based on the benefit of urban rail system investments with a focus on medium-sized cities which are under development are determined by conjoint analysis. One of the main factors affecting the development trend of medium-sized cities is the transportation. As a public transport service, urban rail systems are at the center of focus of developing cities with the benefits they provide. With the conjoint analysis used, it is expressed in the study how the rail system investments in medium-sized cities have a quality in terms of modern requirements.
\end{abstract}

Keywords: Transportation, Urban Rail System, Feasibility, Conjoint Analysis 


\section{GİRIŞ}

Kentlerin ulaşım sistemleri, teknolojiye bağlı olarak her geçen gün gelişmekte ve ulaşım alanında karşılaşılan sorunlara karşı üretilen çözümlerde de geniş bir çözüm yelpazesinin ortaya çıktığ1 görülmektedir. Teknolojik ulaşım sistemlerinin sürekli dünya gündeminde kalmasında enerji tüketimi, yakıt tüketimi, hava kirliliği, çevresel kirlilikler gibi küresel ölçekte yaşanan çeşitli problemlere çözüm üretmek için bir araç olarak kullanılabilmesi etkin olmaktadır. Bu problemler ile uğraşıp olumlu sonuçlar alınması ülkelerin sosyoekonomik gelişmişlik seviyesine göre değişmektedir.

Yaşanan problemler ile mücadele etmenin bir yolu da, ulaşım sektörü üzerinden gerçekleşmektedir. Ülkelerin sosyoekonomik açıdan farklı düzeylerde olması, üretilen çözümlerin de etki ve gelişmişlik seviyesi üzerinde rol oynamaktadır. Türkiye gibi gelişmekte olan ülkelerin her bir kentinde farklı bir dinamik yapının olması kent bazında farklı çözümlerin oluşmasını sağlamaktadır. Bir diğer ifade ile farklı ulaşım çözümlerinin yaşanmasında kentsel seviyede sosyoekonomik farklılıkların olması etkilidir. Teknolojiye bağlı olarak ulaşım alanında üretilen çözümlerin çeşitlenmesi birçok kentin kendi dinamik yapısına göre ulaşım çözümlerinde yeni arayışlara girmesinde itici bir güç olarak görülmektedir.

Çalışma kapsamında yer alan konjoint analizi hizmet konusunda çalışma yapan araştırmacılar tarafindan kullanılan bir yöntemdir. Bu yöntemin en önemli yönlerinden birisi bir hizmet kapsamında ortaya çıan çok yönlü durumun algılanmasında ve gerçekleşmesi istenen duruma ilişkin sayısal sonuçlar verebilmesi olarak düşünülebilir. Bir hizmet göz önünde bulundurulduğunda elde edilecek kalitatif ve kantitatif faydalar olması durumu gerçekleşebilmektedir. İnsanların içinde bulunduğu durumda en fazla faydayı elde etme eğilimi, harcanacak kaynakların akıllıca kullanılmasını gerektiren bir etmen olarak karşımıza çıkmaktadır. Konjoint analizi 1960 - 1970'li yıllardan beri yapılması planlanan hizmet alternatiflerinin fayda yönlerini ele alarak en iyi hizmetin nasıl nitelikte ve hangi düzeydeki özelliklere sahip olması gerektiğine ilişkin hesaplamaları ortaya çıkarmaktadır (Turanlı vd., 2013, s. 4).

Konjoint analizi kullanılarak hizmet ve hizmetin özelliklerine ilișkin düzeylerine yönelik tespitlerin yapılması, daha kaliteli ve yüksek standartta kazanımların sağlanmasının önü açılmaktadır (Yavuz ve Çemrek, 2013, s. 379). Gelişmekte olan ülkelerin kaynaklarını koruma konusundaki tutumu göz önünde bulundurulduğunda konjoint analizinin özellikle gelişmekte olan ülkeler için yatırım kararı almada etkin bir araç olacağı kaçınılmaz olarak görülmektedir. İnsanların yaşam alışkanlıklarının parçalarına dayalı olarak değişim ve dönüşüme giren ihtiyaç taleplerine hizmet arzı ile yerel yönetimler karșılık vermektedir. Bu çerçevede insanların kentsel mekanda ihtiyaç duyduğu gereksinimlerden birisi ise kentsel ulaşım talebi olup bu talebe arz üretmenin birden fazla yolu bulunmaktadır. Yerel yönetimler aracılığıyla insanların ulaşım ihtiyaçları farklı nitelikteki kamusal hizmetlerle sağlanmaktadır. Kullanıcılara yönelik düzenlenen kentsel ulaşım çözümlerinde hem kaynak tüketimi hem de etkili çözümlerin üretilmesi adına çözüm alternatifleri kullanıcıların ihtiyaçlarına tercihlerine göre hassasiyet kazanmalıdır. Konjoint analizi, çok niteliğe sahip olan hizmetlerin kullanıcıları olan bir diğer ifade ile ulaşım talebi olan yolcuların tercihlerinden hareketle yapılabilmektedir.

Modern gelişmelerin sonucunda kentsel alanda toplu taşıma hizmeti için ortaya çıkan son teknoloji ürünlerinden birisi de kent içi raylı toplu taşıma sistemleridir. Kent içi raylı toplu taşıma sistemleri yatırım açısından bir sanayi yatırımından daha çok kamusal bir hizmettir. Sağladığı birçok faydadan dolayı kent içi raylı sistemler son zamanların en tercih edilen kent içi toplu taşıma sistemlerindendir.

Kent içi raylı sistemlerin bir toplu taşıma hizmeti kapsamında ele alınması onu hizmet değerlendirme çalışmalarının bir konusu yapmaktadır. Dolayısıyla, kent içi raylı sistemler hizmet özelliklerine sahip bir yatırım türü olmaktadır. Ulaşım alanında yolcuların kent içi raylı sistemleri tercih etmesi vurgulanan hizmet özelliklerine dayalı olarak gerçekleşmektedir. Kent içi raylı sistemleri yüksek teknoloji içerdiğinden dolayı sağladığı faydaların bir kısmı hizmet özelliklerine ilişkin kavramlardan oluşmaktadır. Kent içi raylı sistemler planlanması oluşturduğu kaynak tüketiminden dolayı bir karar verme problemi olduğundan ve kentlerin geleceği üzerinde doğrudan etki taşıdığından dolayı şehir ve bölge planlama disiplininin ulaşım planlama adlı başlığı adı altında önemli bir bileşen olarak karşımıza çıkmaktadır. Bundan dolayı, hizmet niteliği taşıyan yatırımın uygun ölçüt ve ölçüt düzeyleri ile ilişkilendirilerek değerlendirilmesi ihtiyacı doğmaktadır. 
Kentlerde sosyoekonomik faaliyetlerin kendini yenilemesi durumunda kalkınma faaliyetleri yaşanmaktadır. Kalkınma faaliyetlerinin giderek yaygınlaşmasının sağlanmaya çalışıldığı yerlerden birisi de orta ölçekli kentlerdir. Araştırma, orta ölçekli kentler kapsamında göreceli olarak kaynakların daha sınırlı olması yatırım kararlarının daha akıllıca alınmasını ve ihtiyaca göre şekillenmesini sağlamak için modern bir yaklaşım oluşmasına katkı vermektedir. Araştırmanın katkı verdiği bir diğer unsur ise, yatırım kararlarını etkileyen özellikle orta ölçekli kentlerde ölçütlerin, ölçüt düzeylerinin ve önem derecelerinin neler olduğunu bulmak yönündedir.

\section{KONU - KAPSAM}

Kentlerin ölçeğine dair konularda kesin yargılar bulunmamakla birlikte bu husustaki değerlendirmeler genellikle kent nüfusuna ilişkin çerçevede şekillenmektedir. Bu kapsamda bakıldığında bile küresel ölçekte farklı yorumların bulunduğu görülmektedir.

Örneğin Amerika'da nüfusun 100.000 - 500.000 olduğu yerler, Kanada'da 50.000 - 100.000, Brezilya'da 50.000 - 500.000, Japonya'da 100.000 - 500.000, genel olarak Avrupa'da ise 100.000 250.000 büyüklüğündeki kentler orta ölçekli kentler sınıfında yer almaktadır (Üzmez, 2012, s. 129).

Tablo 1: Orta Ölçekli Kent Nüfusu Ülke Örnekleri (Üzmez, 2012, s. 129)

\begin{tabular}{|l|c|}
\hline Ülke & Aralı (Nüfus) \\
\hline ABD & $100000-300000$ \\
\hline Kanada & $50000-100000$ \\
\hline Brezilya & $50000-500000$ \\
\hline Japonya & $100000-500000$ \\
\hline Avrupa Birliği & $100000-250000$ \\
\hline
\end{tabular}

Orta ölçekli kentler yapılan çalışmalarda büyük ve küçük nitelikteki kentlerin bir karışımı olarak görülmekte ve ikisinin de sahip olduğu avantajların tamamına sahip olarak değerlendirilmektedir. Orta ölçekli kent kavramı ifade edilirken her ne kadar nüfus ölçütü yaygın olarak kullansa da kentin sosyoekonomik, kültürel yapısı, etki alanının büyüklüğü, - odak niteliği etkili olmaktadır (Tanış ve Öğüt, 2007, s. 2).

Orta ölçekli kentler yaşam kalitesi açısından büyük ölçekli kentler ile küçük ölçekli kentlerin arasında yer almaktadır. Orta ölçek kentlerinde kentsel problemler henüz büyük ölçek kentlerinde olan kadar olgun değildir. Türkiye'de de dünyada olduğu gibi kentlerin ölçek bazında değerlendirilmesi kent nüfusuna göre yapılmaktadır.

Özellikle Türkiye tarihine bakıldığında ülkenin yapısına özgü olarak 1950'li yıllarda artmaya başlayan kentleşmenin ülkenin kıyı ve metropoliten alanlara göç edilmesini tetiklediği görülmektedir. Bu durum sonucunda ülkede farklı ölçekte yerleşim alanlarının oluşumu söz konusudur. Türkiye'de kentlerarası ölçek farkının olmasında çeşitli mevzuatlarında etkisi bulunmaktadır. 5393 sayılı Belediye Kanunu, 5216 sayılı Büyükşehir Belediyesi Kanunu bu mevzuatlardan bazılarıdır (Üzmez, 2012, s. 135).

Tablo 2: Kanunlar ve Nüfus Aralıkları (Üzmez, 2012, s. 135).

\begin{tabular}{|l|c|c|}
\hline Kanun & Nüfus & Yerleşme Türü \\
\hline 5393 say1lı Belediye Kanunu & $5000<\ldots \ldots$ & Belediye \\
\hline 5216 sayılı büyükşehir belediyesi kanunu & $750000<\ldots \ldots$ & Büyükşsehir \\
\hline
\end{tabular}


Orta ölçekli kentlerin yapısında ulaşım konusu trafiğe yönelik problemler henüz sorun oluşturmazken bu konuya ilişkin problem orta ölçekli kentlerin nüfusunun artması ile artış göstermektedir. Söz konusu alanda özellikle orta ölçekli kentler için sıkıntı yaşamamak adına yatırımlar modern gereklilikleri kapsayan ölçütlerden oluşan bir yaklaşım ile ele alınmalıdır.

Kentlerde nüfusun artması ile birlikte hareketlilik kavramında da artış görülmektedir. Bu durum sonucunda ise kent içi trafik sorunları üzerinde değişimler yaşanmaktadır. Nüfus ve hareketlilik arasındaki ilişkiden doğan gelişmelerden kentlerin ulaşım sisteminde ölçeğe bağlı olarak kademelenme yaşanmaktadır. (bkz. Tablo 3) (Tanış ve Öğüt, 2007, s. 3).

Tablo 3: Yerleşim ve Ulaşım Türleri Kademelenmesi

\begin{tabular}{|c|c|}
\hline Ölçek & Gelişim - ulaşım ilişskisi \\
\hline \multirow{3}{*}{ Küçük Yerleşimler } & 1. Basamak yaya yolculukları \\
\hline & 2. Basamak motorsuz ve motorlu taşıt yolculukları \\
\hline & 3. Basamak toplu taşımanın gelişimi \\
\hline \multirow{3}{*}{ Küçük Ölçekli Kentler } & 4. Basamak yol ağı gelişmesi \\
\hline & 5. Basamak minibüs faaliyetleri \\
\hline & 6. Basamak tramvay ve otobüs faaliyetleri \\
\hline \multirow{2}{*}{ Orta Ölçekli Kentler } & 7. Basamak özel toplu taşıma yolu \\
\hline & 8. Basamak HRS ve hızlı otobüs \\
\hline Büyük Ölçekli Kentler & 9. Basamak otomatik sistemler \\
\hline
\end{tabular}

Türkiye'de kaynak tüketimine dayalı ve trafiğe dayalı durumlar orta ölçekli kentler için henüz tehdit aşamasındayken gelecekte sorun olma potansiyeline sahiptir. Bu durumun sonucuna bağlı olarak Türkiye'deki orta ölçekli kentlerde yeni ulaşım arayışları ortaya çıkmaktadır. Özellikle orta ölçekli kentler açısından sürdürülebilirliğin sağlanması da göz önünde bulundurulduğunda iyi planlanmış yatırımlara ihtiyaç duyulduğu görülmektedir. Son yıllarda popülerlik kazanan raylı sistem konusu teknolojiye bağl1 olarak çözüm çeşitliliği göstermesi açısından orta ölçekli kentler için uygun bir alternatif olarak karşımıza çıkmaktadır.

Türkiye'de kent içi raylı sistemler, geleneksel ulaşım politikalarının terk edilerek artış gösteren yolculuk eğilimine cevap vermede etkili bir araç olarak kullanılsa da yaygınlaşmasında yerel yönetimler yasal yollarda ulaşım planı hazırlatma zorunluluğu ve ulaşımda enerji verimliliğinin arttırılmasına ilişskin usul ve esaslar hakkında yönetmeliği ile etkileşim içinde bulunmaktadır (Düzkaya vd., 2018, s. 409).

Türkiye'de yatırımların ve planlama faaliyetlerinin özellikle özel araca dayalı olarak gerçekleşmesi konusu kentlerde raylı sistem yaygınlaşmasının önündeki engellerden biri olarak görülmektedir. Bunun bir sonucu olarak, kalkınma faaliyetlerinin hızlı bir ivme ile artış göstermesi gerektiği orta ölçekli kentlerde toplu ulaşım çözümleri Dünya'da birçok ülke ile kıyaslandığında küresel yarışı daha geri bir pozisyondan takip etmektedir (Cirit, 2014, s. 27).

Kent içi raylı sistemler Türkiye'de birçok kentin ulaşım alanında yaşadığı sıkıntıları çözmek için bulunsa da yaygınlaşma açısından doğrudan bir ulaşım planlama arayışı ile entegre değildir. Kent içi raylı sistemlerden maksimum anlamda verim alınabilmesi için planlama çalışmalarının doğru ve özenli bir şekilde ele alınmasını gerektirmektedir. Kent içi raylı sistemler özetle, kentlerde daha iyi bir toplu taşıma hizmeti vermenin anahtar elemanıdır (Özden, 2012, s. 1). 
Kent içi raylı sistemler, belirli güzergâh üzerinde yer alan, kentsel arazi üzerinde sabit bir mekân kaplayan, birim zamanda kent merkezine daha fazla insan taşımaya elverişli olan toplu taşıma sistemleridir (Aktan, 2005, s.156 ). Kent içi raylı sistemler modern zamanların en güvenilir toplu taşıma türleri arasında görülmektedir. Metropoliten alanlarda oluşturduğu faydalardan dolayı sıkça tercih edilmektedir. Bu faydanın oluşumunda en önemli etkenlerden birisi, kent içi raylı sistemlerin yolcu taşımadaki performansıdır (Candemir ve Tanyel, 2005, s. 309).

Geniş bir tercih alternatifi bulunan kent içi raylı sistem türleri ulaşım sorunlarının çözümünde etkili bir araç olarak kullanılabilmektedir. Tramvay, hafif raylı sistem, metro, cadde tramvayı gibi sistemler örnek olarak gösterilebilir. Söz konusu sistemler; yolcu kapasitesi, minimum sefer sıklığı, trafikten izole olup olmama gibi teknik yönler göz önünde bulundurulduğunda birbirinden farklı özellikler taşıyabilmektedir (Öğ̈̈t ve Evren, 2006, s. 2).

Kent içi raylı sistemler teknik üstünlüklerinin yanı sıra, ulaşımda çevre dostu bir alternatif niteliği de taşımaktadır. Özellikle hafif raylı sistem ve cadde tramvayları nüfus ve trafiğin fazla olduğu yerlerde uzun güzergâhlar için yolculuklar için iyi bir alternatif olabilmektedir. Kent içi raylı sistemlerin yapılma nedenlerinden birisi de karayolu yatırımlarının artış göstermesinden dolayı karayolu araçlarının çevreyi verdiği zararların azaltmasını sağlamaktır (Thompson ve Jones, 2000, s. 519).

Kent içi raylı sistemlerin yatırımlarda gerekçe olarak gösterilebilecek birden çok yönü bulunmaktadır. Kentte geliri alt düzeyde olan ve hareketlilik talebi yüksek olan kişiler gelirlerinin önemli bir kısmına harcadığından hanehalkı gelirinin ulaşıma ait payının düşürülmesinde kent içi raylı sistemler etkin bir yatırımdır. Bu yönüyle, kent içi raylı sistemler aynı zamanda sosyal bir kalkınma aracı olarak görülmektedir.

Kent içi raylı sistemlerinin yapılı alanlara odaklanması durumu kimi zaman daha özelleşmiş çözüm arayışlarını gerektirebilmektedir. Bu durum, teknik yönüyle birbirinden farklı kent içi raylı sistem türlerinin kent içinde yer almasını gerektirebilmektedir. Bu kapsamda kent içinde karşılaşılan raylı sistem türlerinden birisi de cadde tramvayı olarak karşımıza çıkmaktadır.

Cadde tramvayları teknolojinin gelişmesi ile birlikte kentsel alanlarda yaygınlaşan kent içi raylı sistem türlerinden birisidir. Cadde tramvayları kentsel trafik sirkülasyonu ile kolayca entegre olabilmekte ve değişen trafik koşullarına göre hareket edebilmektedir. Kentsel trafikle eşgüdüm içinde hareket eden cadde tramvaylarının kullanımı genişleyebilmektedir. Cadde tramvaylarının bir başka özelliği olan kılavuzlanmış olma özelliklerine ek olarak yolcu kapasitesi açısından 7.000 yolcu/saat/yön kapasitesine kadar hizmet sağlayabilmektedir. (Öğ̈̈t ve Evren, 2006, s. 3; Önder ve Akdemir, 2019, s. 33).

Erzincan kenti günümüzde gerek bulunduğu pozisyon gerekse bünyesindeki diğer zenginlikten dolay1 yerel otoritelerin dikkatini çekmiş birden çok projeye mekânsal anlamda ev sahipliği yapan bir yerdir. Yüksek hızlı tren, lojistik üs, havalimanı, gar, otogar gibi yatırımlar yanında kent gelişiminin ulaşım ana planı incelendiğinde cadde tramvayı önerisi görülmektedir. Erzincan ulaşım ana planı Erzincan kentinin ulaşım sorunlarına çözüm arayışı amacıyla oluşturulmuş bir çalışma olarak karşımıza çıkmaktadır. Çalışmanın sonuç önerisi olarak, kente cadde tramvayı projesi yapılması gerektiği ifade edilmektedir. Erzincan ulaşım ana planının 2017 yılının Nisan ayında Gazi Üniversitesi bünyesindeki Kent İçi Ulaşım Teknolojileri Erişebilirlik, Uygulama ve Araştırma Merkezi (KUTEM) tarafindan tamamlandığı görülmektedir (Düzkaya vd., 2018, s. 7).

Erzincan ulaşım ana planı 2032 yılına yönelik yapılan tahmin çalışmaları çerçevesinde şekillenmektedir. $\mathrm{Bu}$ çalışmalar doğrultusunda gelecekte ulaşım alanında yaşanabilecek olası darboğazlar, sorunlar, yetersizlikler tespit edilerek senaryo önerilerinin geliştirilmesi söz konusudur. Geliştirilen senaryolarda toplu taşım sistemi olarak cadde tramvayına yer verildiği görülmektedir. Cadde tramvayının kentin ulaşım problemlerini çözmede bir araç olarak kullanılabilmesinde temel gerekçe olarak ilgili kent içi raylı toplu taşıma sisteminin yolculuk maliyeti, yatırım maliyeti, hava kirliliği, gürültü kirliliği, enerji tüketimi ve erişim süresi konusunda sağladığı yararlar vurgulanmaktadır (KUTEM a, 2017, s.176).

Erzincan ulaşım ana planının bir sonucu olarak ortaya çıkan cadde tramvayı projesinin teknik yönleri şu şekildedir. Cadde tramvayı projesi süre olarak 2017 - 2032 yıllarını kapsamaktadır. 2017 - 2018 yılları içinde inşa edilmesi planlanan sistemin 2019 yılının sonuna doğru kentsel yolculuklara katkı vermesi 
beklenmektedir. Toplamda 27,7 km'lik bir uzunluğa sahip olan sistemin 22,5 km'lik kısmının birinci etap (2017-2018) kalan kısmının ise ikinci etapta (2026-2027) yapılacağı ifade edilmektedir (KUTEM b, 2017, s.169). Toplamda 32 duraktan oluşan Erzincan kent içi raylı sistem önerisi arazi kullanımı açısından incelendiğinde kentsel kullanımlara eşit şekilde hizmet vereceği düşünülmektedir (Bkz. Şekil $1)$.

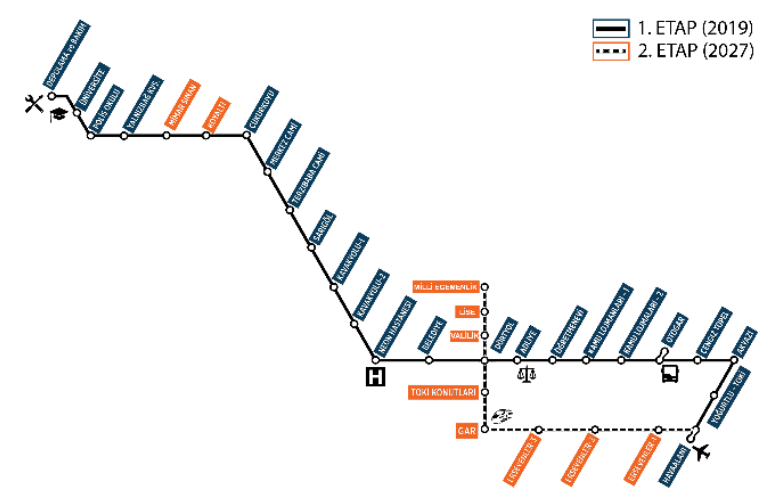

(a)

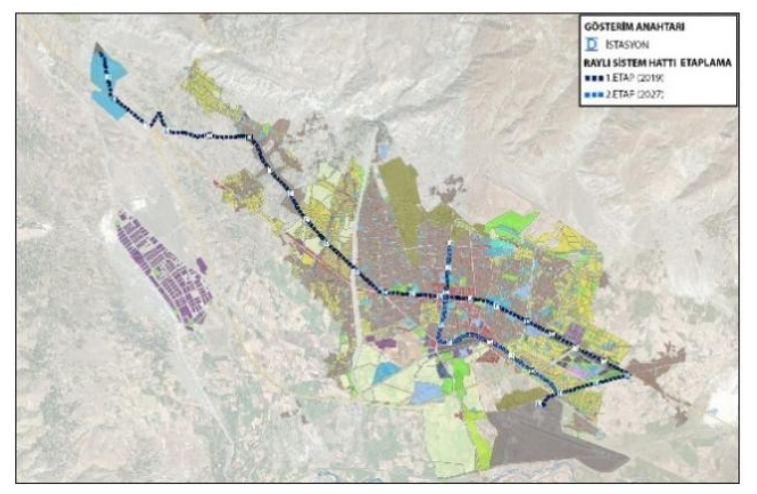

(b)

Şekil 1: Erzincan cadde tramvayı şeması (a) Arazi kullanımı ve istasyonlar (b)

Kaynak: KUTEM Arşivi 2017

Erzincan Cadde tramvayı projesi kapsamında cadde tramvayının teknik özellikleri tablo 4'te olduğu gibidir. Projenin 2019 yılında zirve saatteki tek yön yolcu sayıs1 7.860 yolcu/yön/saat iken 2032 yılındaki zirve saatteki tek yön yolcu sayısı 14.921 yolcu/yön/saat şeklindedir.

Tablo 4: Erzincan Cadde Tramvayı Teknik Özellikleri

\begin{tabular}{|l|c|c|c|c|}
\hline Teknik Özellik & 2019 & 2022 & 2027 & 2032 \\
\hline Hız (km/sa) & 35 & 35 & 35 & 35 \\
\hline Mesafe (km) & 21 & 21 & 27.7 & 27.7 \\
\hline Süre (dk) & 36 & 36 & 47.5 & 47.5 \\
\hline Rotasyon Süresi (dk) & 79.7 & 79.7 & 105.6 & 105.6 \\
\hline Sefer Sayısı & 11 & 12 & 15 & 18 \\
\hline Dizi Kapasitesi & 400 & 400 & 400 & 400 \\
\hline Zirve Saatte Tek Yönde Yolcu Sayıları (Yolcu/Yön/Saat) & 7.860 & 8.772 & 12.262 & 14.921 \\
\hline Zirve Saatte En Yüksek Kesit Değeri (Yolcu/Yön/Saat) & 4.477 & 4.814 & 5.810 & 7.206 \\
\hline Dizi Sayısı & 6 & 7 & 12 & 14 \\
\hline Sefer Sıklığı (dk) & 6 & 5 & 4 & 3,3 \\
\hline Toplam Kapasite & 4.400 & 4.800 & 6.000 & 7.200 \\
\hline Gerekli Araç Sayısı & $12(+2)$ & $14(+2)$ & $22(+2)$ & $28(+2)$ \\
\hline
\end{tabular}

Erzincan Cadde tramvayının ulaşım ana planını kapsamında çok ölçütlü değerlendirme çalışmaları sonucunda önerildiği görülmektedir. Ulaşım ana planında çok ölçütlü değerlendirme bileşeni yatırım 
senaryosunun belirlenmesinde anahtar rol oynamaktadır. Çok ölçütlü değerlendirme çalışmalarının gerçekleştirilmesinde yatırımın ekonomik, sosyal ve çevresel yönlerinin de etkili olduğu vurgusu yapılarak Erzincan kentinin ulaşım sorunlarından hangi senaryonun daha faydalı çözümü sağlayacağına yönelik bir arayış yer almaktadır.

Her ne kadar ulaşım ana planı kapsamında cadde tramvayının dolayısıyla kent içi raylı sistemlerinin farklı faydaları vurgulansa da projenin uygulanması fizibilite çalışmasının yapılmasına ve ekonomik/mali anlamda yapılabilir çıkmasına dayalı olarak değişkenlik göstermektedir.

UDHB'nın DLH Ulaşım ve Fizibilite Etüdü Teknik Şartnamesine bağlı kalınarak hazırlanan Erzincan kent içi raylı sistem fizibilite çalışmalarının Zirve Saat Tek Yönde Yolcu Sayısı, Net Bugünkü Değer, İç Verimlilik Oranı, Geri Ödeme Süresi, Fayda Maliyet oranı gibi teknikler üzerinden yapılabilirliği tartışlmaktadır (DLH, 2014,s. 30 ; KUTEM b, 2017, s.173).

Tablo 5: Fizibilite Teknikleri

\begin{tabular}{|l|l|l|}
\hline Tekniğin Adı & Yöntemi & Yorumu \\
\hline NBD (Net Bugünkü Değer) & $\begin{array}{l}\text { Gelirlerin giderlerden ne } \\
\text { kadar farklı olduğunu bulmak }\end{array}$ & $\begin{array}{l}\text { En büyük pozitif sonuç en iyi sonuç } \\
\text { olarak değerlendirilmektedir. }\end{array}$ \\
\hline IVO (İç Verimlilik Oranı) & $\begin{array}{l}\text { İndirgeme oranının Gelirleri } \\
\text { giderlere eşitleyen değerinin } \\
\text { çıkarılması }\end{array}$ & $\begin{array}{l}\text { İç verimlilik oranı indirgeme } \\
\text { oranından büyük ise yatırım } \\
\text { yapılabilir. }\end{array}$ \\
\hline FMO (Fayda Maliyet Oranı) & $\begin{array}{l}\text { Fayda ve maliyetlerin } \\
\text { günümüze indirgenmiş } \\
\text { oranlanması }\end{array}$ & $\begin{array}{l}\text { Fayda maliyet oranı 1'i geçerse } \\
\text { yatırım yapıllabilir. }\end{array}$ \\
\hline Geri Ödeme Süresi & $\begin{array}{l}\text { Gelirlerin } \\
\text { karşladığı zamanın ifadesi }\end{array}$ & $\begin{array}{l}\text { Daha kısa sürede kendini ödeyebilen } \\
\text { projelerin daha iyi olduğu kabul } \\
\text { edilmektedir. }\end{array}$ \\
\hline
\end{tabular}

Kent içi raylı toplu taşıma projesi olan Erzincan Cadde tramvayı projesinde de aynı sürecin izlenmiş olduğu projenin fizibilite çalışmaları kapsamında üretilen 3 farklı finansal modele göre yapılabileceği görülmektedir. Bu modeller sirasıyla \%30 Özsermaye - \%70 Kredi, \%100 Kredi Finansman1, \%100 Devlet Fonu şeklindedir. Her üç modele göre de projenin yapılabilir olarak çıkması durumu proje kapsamında elde edilecek gelirlerden ve projenin oluşturduğu ekonomik faydadan kaynaklanmış şekilde ifade edilmektedir (KUTEM b, 2017, s.175).

Erzincan ulaşım ana planı çalışmasında görüldügü şekliyle yatırımın yapılabilirliği anlamında fizibilite çalışmalarının etkili olduğu görülmekte iken yatırımın ekonomik faydalarının dışında sosyal ve çevresel faydalarına dayalı durumların yatırımın yapılabilirliğine ilişkin ulaşım ana planı kanalı üzerinde dolaylı etkisi bulunmaktadır. Bir diğer ifade ile kent içi raylı sistem yatırımı birçok fayda oluştururken yapılabilirlik çalışmaları sadece ekonomik faydaları değerlendirebilecek yeterlilikte olduğundan yatırım kararı da ekonomik ölçütler üzerinden alınmaktadır.

\section{RAYLI SISTEM YATIRIM ÖLÇÜTLERININ KONJOİNT ANALIZİ}

Konjoint analizi problem olarak ele alınan hizmetleri, hizmet özelliklerinden yararlanarak değerlendirmeye olanak sağlamaktadır. Bu analiz sonucunda kullanıcılar tarafından, ilgililer tarafından sağlanması istenen hizmetin en faydalı olarak görülen özellikleri ve düzey dereceleri ortaya konulmaktadır. Temel olarak konjoint analizinde hizmet ve hizmetin düzeylerine ilişkin yapılan detay araştırmaları sonucunda kombinasyonlar oluşturulmakta ve oluşturulan kombinasyonların istatistiksel yorumlanması en fazla arzulanan hizmetin ve niteliklerinin ne olduğunu anlamaya yardımcı olmaktadır (Aktaş vd., 2012, s, 26). 
Kent içi raylı sistemler gibi hizmet türlerinin soyut ve somut birden fazla faydası olabilmektedir. Bunlar doğrudan ulaşım ile ilgili parametreler olup temel olan parametreler şu şekilde sıralanabilir: Hava kirliliği, Ücretlendirme, Güvenlik, Konfor vb. Örnek parametrelerde görüldüğü gibi ücretlendirme konusunda kullanıcıların beklentileri doğrudan sayısal bir miktar ile kolayca anlaşılabilir hale getirilebilir bir durumda iken, güvenlik, konfor gibi parametreler ücretlendirme örneğinde olduğu gibi kolayca sayısal hale getirilememektedir.

Konjoint analizi aracılığıyla sayısal hale gelemeyen hizmet özellikleri de sayısal hale getirilerek kullanıcıların hizmet üzerindeki beklentisine yönelik olarak hizmette iyileştirme veya yatırım kararı değişimleri yapılmasına imkan bulunmaktadır. Her bir kullanıcı tercih ettiği hizmet özelliği ve özelliğin düzeyine ilişkin kendine göre bir tercih nedeni bulundurmaktadır. Bu durum konjoint analizi kapsamında hizmet özelliklerine dayalı kombinasyonların kullanıcı tercihlerini anlamaya olanak verir şekilde tasarlanmasını gerektirmektedir (Noyan ve Yalçın, 2016, s.27; Gürbüz ve Kaygısız, 2004, s. 142).

Konjoint analizinin iş akış şeması bir bütün olarak ele alındığında: (Yavuz ve Çemrek, 2013, s. 383)

Tablo 6: Konjoint uygulama akışşeması

\begin{tabular}{|l|}
\hline Araştırma Probleminin Belirlenmesi \\
\hline Hizmete İlişkin Ölçüt ve Düzeylerinin Tespit Edilmesi \\
\hline Ölçütlerin Düzey Özelliklerine Bağlı Kombinasyonların (Kartların) Oluşturulması \\
\hline Veri Toplama Tekniği Belirleme \\
\hline Analiz \\
\hline Analiz Sonuçları \\
\hline Sonuçların Yorumlanması \\
\hline
\end{tabular}

Genel olarak tablo 5'teki süreç takip edilmektedir.

Konjoint modeli ile çalışmanın birçok avantajı bulunmaktadır. Hizmetin ortaya çıkmasından önce eğilim ile ilgili bilgiler vermektedir. Sonuçları kolayca yorumlanabilmektedir. Hem sayılabilir hem de sayılamayan sonuçların yorumlanması kolaydır. Bireysel seviyelerde ölçüm yapmaya elverişlidir. Birden çok özelliği ve özelliğin düzeyine ilişkin ölçümler yapmaya imkân vermektedir.

Konjoint analizi 3 farklı teknikten oluşmaktadır. Bu teknikler sırası ile:

\section{1 - Geleneksel Konjoint Analizi}

2 - Seçime Dayalı Konjoint Analizi

3 - Uyarlamalı Konjoint Analizi

şeklindedir. Teknikler genel olarak konjoint yaklaşımının temel durumunu oluşturan hizmet ve hizmet özelliklerini belirlemeye yönelik olarak kullanılmakta iken değerlendirilen duruma göre hangi tekniğin kullanılması durumu farklı1ık gösterebilmektedir. Seçime dayalı konjoint analizi, çok fazla sayıda özellikten ve oluşan hizmetler için elverişlidir (Turanlı vd., 2013, s. 7; Noyan ve Yalçın, 2016, s. 30).

Konjoint Analizi özellikle ulaşım alanında yaygın ve özel alanlara yönelik çalışmalarda kullanılmaktadır. Konjoint analizinin ulaşım alanında kullanıldığı örnek çalışmalar için Bkz. Tablo 7 
Tablo 7: Konjoint Analizi Kullanılan Çalışmalar

\begin{tabular}{|c|c|c|}
\hline Çalışmanın Ad 1 & Yap1ldığ Y Y1l & İçerik \\
\hline $\begin{array}{l}\text { Preferences and trip expenditures - a conjoint analysis } \\
\text { of visitors to Seoul, Korea, (Kun Suh ve Gartner, 2004, s. 328) }\end{array}$ & 2004 & $\begin{array}{l}\text { Ulaşımda Tercih } \\
\text { ve Harcamaları }\end{array}$ \\
\hline $\begin{array}{l}\text { Conjoint Analysis Based Transit Service Quality Research } \\
\text { (Liu, Deng ve Zhang, 2011, s. 99) }\end{array}$ & 2011 & $\begin{array}{l}\text { Ulaşım Hizmet } \\
\text { Kalitesi }\end{array}$ \\
\hline $\begin{array}{l}\text { Forecasting the Market for Electric Vehicles in California } \\
\text { Using Conjoint Analysis (Segal,1995, s. 94) }\end{array}$ & 1995 & $\begin{array}{l}\text { Elektrikli Özel } \\
\text { Araçların Market } \\
\text { Tahmini }\end{array}$ \\
\hline $\begin{array}{l}\text { A Study On Evaluation Of Pedestrian Level Of Service Along } \\
\text { Sidewalks And At Crosswalks Using Conjoint Analysis } \\
\text { (Muraleetharan vd, 2004, s.727) }\end{array}$ & 2004 & $\begin{array}{l}\text { Yaya Yolları ve } \\
\text { Kaldırımlar }\end{array}$ \\
\hline $\begin{array}{l}\text { Conjoint Analysis and a Practice in Arrival Sector, (Gürbüz ve } \\
\text { Kaygisiz, 2004, s.143) }\end{array}$ & 2004 & $\begin{array}{l}\text { Ulaşım Sektör } \\
\text { Pazarı }\end{array}$ \\
\hline $\begin{array}{l}\text { Improving conditions for potential New Zealand cyclists: An } \\
\text { application of conjoint analysis. (Wooliscroft ve Ganglmair - } \\
\text { Wooliscroft,2014, s.14) }\end{array}$ & 2014 & Bisiklet \\
\hline $\begin{array}{l}\text { How to capture the passengers' point of view on a transit } \\
\text { service through rating and choice options. (Eboli ve Mazulla, } \\
\text { 2010, s.445) }\end{array}$ & 2010 & $\begin{array}{c}\text { Yolcu } \\
\text { Memnuniyeti }\end{array}$ \\
\hline $\begin{array}{l}\text { Robust models for the utilization of public bus transport } \\
\text { services in Malaysia. (Jayaraman vd, 2011, s.10590) }\end{array}$ & 2011 & $\begin{array}{l}\text { Toplu Taşıma } \\
\text { (Otobüs) }\end{array}$ \\
\hline $\begin{array}{l}\text { Modeling freight transportation preferences: Conjoint } \\
\text { analysis for Turkish Region (Köfteci vd., 2010, s. 2018) }\end{array}$ & 2010 & Yük Taşımacılığı \\
\hline
\end{tabular}

Tablo 7'de görüldüğü üzere; konjoint analizi ulaşımın birçok alanında kullanılmaktadır. Konjoint analizi, özellikleri ölçülmek istenen hizmete ilişkin tespitleri, hizmetin düzeyine ilişkin tespitleri, konjoint çalışmasının gerçekleştirilmesine konu olan hizmete ilişkin konjoint uygulama formunun oluşturulması, bilgisayar programlarından yararlanılarak etki analizinin yapılmasını içermektedir (Yavuz ve Çemrek, 2013, s. 384, Gürbüz ve Kaygısız, 2004, s. 145). Bir diğer ifade ile konjoint analizi yapan araştırmacı öncelikle araştırma konusuna ilişkin hizmetin ne olduğunu anlamalıdır. Bunu takip eden adımda araştırmaya konu olan hizmetin özelliklerine ilişkin ölçütler, düzeyler tespit edilmektedir. Yapılan tespitler sonucunda hizmetin özellik düzeylerinin farklı derecelerde bir araya geldiği kombinasyonlar getirilmektedir. Bu kombinasyonların bir araya geldiği forma genellikle kart adı verilmektedir. Birçok özellik ve düzeye bağlı olarak oluşabilecek kombinasyon sayısı fazla olabileceğinden dolayı yöntemin uygulanması açısından gerçekleşmesi daha mümkün kombinasyonlar kullanıcıların tercihlerini anlamada daha etkili olmaktadır (Yavuz ve Çemrek, 2013, s. 389; Gürbüz ve Kaygısız, 2004, s. 141; Aktaş vd., 2012, s, 27).

Kombinasyonların oluşturulması, bir diğer ifade ile aynı soruna ölçütlerin farklı düzeylerinin bir araya gelerek oluşturduğu birleşimleri yani çözüm senaryolarını ifade etmektedir (Yiğit ve Çevik, 2011, s. 106). Kullanıcıların oluşturulan kombinasyonların kendilerine verilen problem karşısında kendi tecrübelerine 
göre ele alıp kombinasyonlar çerçevesinde kullanılan konjoint tekniğine göre değerlendirme yapması izlemektedir (Saraçlı ve Şıklar, 2005, s.2).

$\mathrm{Bu}$ değerlendirmede kombinasyonların sıralanması veya değiş - tokuş edilmesi gibi yöntemlerden birisi tercih edilerek kullanıcıların verilen kombinasyonlara bakış açısı üzerinden arzuladıkları hizmet ve hizmet düzeyi üzerindeki yorumları elde edilmektedir (Soykan, 2009, s.11). Kombinasyonların sıralanması konjoint uygulamasına konu olan kişilerin verilen kombinasyonlar arasında ilgili sorun için en etkili çözümü oluşturan kombinasyondan en etkisiz çözümü sağlayan kombinasyona kadar kombinasyonları 1'den eldeki son kombinasyon sayısına kadar tekrar etmeksizin siralamayı kapsamaktadır. Kombinasyon sayısı arttıkça yapılması gereken işlemin çok olması analizin bilgisayar programları aracılığı ile gerçekleşmesini tercih ettirebilmektedir (Cengiz ve Girginer, 2012, s.277).

Günümüzde genellikle kombinasyonların sıralamaya dayalı çözümlenmesinde bilgisayar programları etkin bir şekilde kullanılmaktadır (Gürbüz ve Kaygısız, 2004, s.141). Konjoint çalışmaları kapsamında üretilen kombinasyonlar için kullanıcıların sıralama yapması gerektirmektedir. Bu sıralama önceden de ifade edildiği gibi konjoint çalışmasına konu olan problem ile ilgili tecrübelerine dayalı olup soruna çözüm sağlayan en iyi kombinasyondan en kötü kombinasyona doğrudur. Bu durum sonucunda bilgisayar programında analiz yapılarak fayda tahminlerine yönelik katsayılar elde edilmektedir. Dolayısıyla problem için araştırmaya konu olan ölçüt ve ölçüt düzeylerine ilişkin eğilim fayda tahminlerine yönelik katsayılar aracılığıyla yani sayısal sonuçlar ile belirlenebilmektedir (Arslan, 2016, s.315). Sonuç olarak ortaya çıkan durumda ise konjoint analizinin konusunu oluşturan uygulamayı yapan kullanıcıların, yapmış olduğu sıralama üzerinden ilgili kullanıcı grubunun değerlendirilen hizmetin hangi özelliğine hangi düzeyde önem verdiği tespit edilmektedir (Sönmez, 2006, s.186).

$\mathrm{Bu}$ çalışma kapsamında konjoint analizinin kullanılma sebebi mevcutta yaygın olarak kullanılan yatırım kararı alınması sürecinde modern gereklilikleri karşılayabilen bir bakış açısı oluşturmaktır. Bundan dolayı çalışma kapsamında konjoint analizine konu olan durum ekonomik, sosyal ve çevresel açıdan faydaları olan kent içi raylı sistemler, kamusal bir hizmet olarak değerlendirilmektedir. Kent içi raylı sistem yapılması için mevcuta ek olarak sosyal ve çevresel faydaların ne düzeyde olduğunun anlaşılması kent içi raylı sistemlerin yaygınlaşmasında etkili olacağı düşünülmektedir.

Konjoint analizinin konusu olan kent içi raylı sistem hizmetinin özellikleri ve özellik düzeylerinin belirlenmesi analizi tamamlamak için gerekli temel unsurdur. Konjoint analizinin yapılması için kent içi raylı sistem hizmetinin özellikleri ve ölçüt düzeyleri çalışma konusu kent içi raylı sistem olan diğer proje ve çalışmalardan yararlanılarak bir diğer ifade ile literatürden yararlanılarak elde edilmektedir.

Her ne kadar literatür ölçütler ve ölçüt düzeyleri açısından zengin olsa da çalışmada kolaylık olması açısından bu çalışmada kapsamlı olan ölçüt ve ölçüt düzeyleri tercih edilmektedir. Çalışmada ekonomik, sosyal ve çevresel olarak birbirinden farklı olarak 7 adet ölçüt kullanılmaktadır. Kullanılan ölçütler sırası ile ;

1- Yatırım Karlılığı (Zak, 2011, s. 7)

2- Yolculuk Süresi (Newman, 2012, s. 3; Önder ve Akdemir, 2019, s. 23; Tüydeş Yaman, Dalkıç, 2019, s. 255)

3- Konfor (Wardman, 2014, s. 9; Önder, 2016, s. 27)

4- Emisyon (Jain vd., 2014, s. 61)

5- Mekânsal Tüketim (Şahin, 2012, s. 34; Babalık Sutcliffe, 2002, s.425)

6- Rant (Kılıçaslan, 2015, s. 453)

7- Çevresel Kirlilik (Wardman, 2014, s. 12)

Şeklinde olup ölçütlerin düzeylerine ilişkin kavram ve değerlerde yine literatürden elde edilmektedir.

Konjoint analizi kullanılarak kent içi raylı sistemler için yeni ölçütlerin geliştirilmesi için değerlendirilen ölçüt ve ölçüt düzeyleri mevcut yapılabilirlik anlayışına karşılık olarak sadece ekonomik temelli olmayıp yapılacak yatırımların sosyal ve çevresel anlamda üreteceği faydaları da göz önünde bulundurma yönüyle dikkat çekmektedir.

$\mathrm{Bu}$ çalışmadaki konjoint analizi kapsamında yatırım karlılığı kent içi raylı sistem hizmetleri açısından yatırım maliyeti, işletme karlılığı gibi unsurları kapsamakta olup öz bir ifade ile yatırımın kendini geri 
ödeme durumuna yönelik bir ifadedir. Düzey anlamında yatırım karlılığı için geri ödeme süresi 1-5-10 yıl düzeyleri kullanılarak konjoint analizi uygulayıcılarının yatırım karlılı̆̆ı konusundaki eğilimi incelenmektedir.

Bir diğer ölçüt ise, yolculuk süresi olup çalışma kapsamında yolculuk süresi, yapan kişinin yolculuğuna başladığı ve bitirdiği nokta arasında harcadığı zaman toplamı olarak ele alınmaktadır. Bu ölçüt kapsamında düzeyler, yatırımın yapılması ile birlikte yolculuk süresinin mevcut durumdan daha az, değişme göstermeyen ve mevcut durumdan daha fazla olacağ şeklinde değerlendirilmektedir. İnsanların yapmış oldukları aktivitelerin ekonomik anlamda bulunulan yerleşim için bir karşılığı olduğundan yolculuk süresinin ekonomik bir ölçüt olacağı düşünülmekte iken yolculuk süresinin artması ile birlikte insanların psikolojik yönünde negatif etkilerin uyanması yolculuk süresinin sadece ekonomi temelli olmayıp sosyal yönü de etkileyen bir ölçüt olduğunu işaret etmektedir.

Çalışma kapsamında yer alan ve soyut bir kavram olan bir diğer ölçüt ise, konfor kavramıdır. Konfor kavramı yolculuğun rahat ve istenen bir şekilde tamamlanıp tamamlanmadığının bir ölçüsü olarak kişiden kişiye farklılık göstermektedir. Yolculuk yapan kişilerin konfor durumuna göre psikolojileri üzerinde bir etki olması durumu söz konusudur. Bundan dolayı çalışmada sosyal yöne hitap eden bir ölçüt olarak değerlendirilmektedir. Düzey olarak ise, konjoint analizi sonuçlarında uygulayıcıların konfor konusuna olan eğilimi konfor öncelikli olma ve konfor önceliksiz olma açısından incelenmektedir.

Kent içi raylı sistemlerin yapılma gerekçeleri arasında emisyon sıklıkla yer alan bir unsurdur. Ülkelerin emisyon konusunda izledikleri tutum araçlardan kaynaklı olarak salınan gazların düşürülmesi için çeşitli önlemler almak şeklindedir (Önder ve Kaplan, 2017, s. 139). Bu konuda özellikle ulaşım alanında müdahale etmenin yollarından birisi de kent içi raylı sistemlerin yaygınlaştırılmaya çalışılması ile özel araç trafiğini azaltmaktır. Emisyon gazlarının varlığını azaltmak için yatırımların gündeme gelmesi ekonomik anlamda kaynak tüketimini oluşturmaktadır. Salınan gazlar ayrıca hava ile doğrudan etkileşimde bulunduğundan insan sağlığı üzerinde negatif yönde etki potansiyeline sahip bir unsur olarak karşımıza çıkmaktadır. Gerek insan sağlığı gerekse çevre üzerindeki çeşitli olumsuz etkilerinden dolayı emisyon gazları çalışmadaki konjoint analizi kapsamında ekonomik, sosyal ve çevresel niteliğe sahip bir ölçüt olarak değerlendirilmektedir.

Kent içinde yapılan birçok yatırım somut anlamda var olabilmek için belirli miktarda bir mekâna gereksinim duymaktadır. Bundan dolayı yer seçim kararlarının doğru yapılması değerli kent arazilerinin kullanımı açısından önem arz etmektedir. Kent içi raylı sistemler gibi projeler her zaman yapılaşmış alanların yoğun olduğu bölgelerden geçmemektedir. Yapılaşmanın yoğun olmadığı alanlar nitelik olarak yapılaşmış alanlara göre çevresel dokusu daha doğal olan alanlardır. Yapılaşma seviyesi daha az olan alanlara hitap eden kent içi raylı sistem projelerinin çevresel dokusu daha doğal ve yoğun olan alanlardan gerektiğinden fazla geçtiği durumlardan insanların gereksinim duyduğu çevresel doğal dokunun bozulması söz konusu olabilmektedir. Bundan dolayı çalışmanın konjoint analizinde mekânsal tüketim kavramı çevresel ve sosyal yönü etkileyen bir ölçüt olarak ele alınmaktadır.

Mekânsal tüketim konusuna ek olarak yapılacak kent içi raylı sistem yatırımlarının çevresi üzerinde oluşturduğu ekonomik anlamda değişiklikler yaşanmaktadır. Ekonomik faydalar göz önünde bulundurulduğunda yatırımın yapılması ile birlikte özellikle kent içi raylı sistem yatırımlarında genellikle kent içi raylı sistem güzergâhına yakın alanlarda pozitif yönde değer artışları yaşanmaktadır.

Pozitif nitelikte olan değer artışlarının bir ifadesi olan rant kavramı ölçüt olarak değerlendirilen bir diğer kavram olup konjoint uygulayıcılarının kent içi raylı sistemler açısından rant konusundaki eğilimi değerlendirilmektedir.

Yapılan bir yatırımın somut anlamda mekanda var olmasının fiziksel sonuçları doğabilmektedir. Bunlardan bazıları görsel bazıları ise işitseldir. Görsel anlamda yapılan yatırımın çevresi ile estetik anlamda bir uyumsuzluğunun olması görsel kirlilik oluşturabilirken, işitsel anlamda ise yapılan yatırımın oluşturabileceği yüksek ses sonucunda gürültü oluşabilmektedir. Bu kavramlar çevre üzerinde doğrudan etkili olduğundan çalışmanın konjoint analizinde çevresel kirlilik ölçütü adı altında değerlendirilmektedir. 
Kent içi raylı sistem yatırım ölçütlerinin konjoint analizi kapsamında ölçüt ve ölçüt düzeyleri ve nitelikler tablo 8'de olduğu gibidir.

Tablo 8: Ölçüt, Düzey ve Nitelikler

\begin{tabular}{|c|c|c|}
\hline Ölçüt & Düzeyler & Nitelik \\
\hline \multirow{3}{*}{ Yatırım Karlılığ 1} & $1 Y_{11}$ & \multirow{3}{*}{ Ekonomik } \\
\hline & 5 Y11 & \\
\hline & 10 Yil & \\
\hline \multirow{3}{*}{ Yolculuk Süresi } & Mevcut süreden daha kısa & \multirow{3}{*}{ Ekonomik + Sosyal } \\
\hline & Mevcut süre değişmiyor & \\
\hline & Mevcut süreden daha uzun & \\
\hline \multirow{2}{*}{ Konfor } & Konfor öncelikli & \multirow{2}{*}{ Sosyal } \\
\hline & Konfor önceliksiz & \\
\hline \multirow{2}{*}{ Emisyon } & Mevcuttan fazla & \multirow{2}{*}{ Ekonomik + Sosyal + Çevresel } \\
\hline & Mevcuttan az & \\
\hline \multirow{3}{*}{$\begin{array}{l}\text { Mekânsal } \\
\text { Tüketim }\end{array}$} & $\mathrm{Az}$ & \multirow{3}{*}{ Sosyal + Çevresel } \\
\hline & Orta & \\
\hline & Çok & \\
\hline \multirow{3}{*}{ Rant } & Düşük & \multirow{3}{*}{ Ekonomik } \\
\hline & Orta & \\
\hline & Yüksek & \\
\hline \multirow{3}{*}{ Çevresel Kirlilik } & $\mathrm{Az}$ & \multirow{3}{*}{ Çevresel } \\
\hline & Orta & \\
\hline & Çok & \\
\hline
\end{tabular}

Konjoint analizi kapsamında her bir ölçüt ve ölçüt düzeyine ilişkin olarak 972 adet kombinasyon (kart) oluşmaktadır. Ancak çalışmanın uygulanması açısından 972 kart çok fazla olduğundan ölçütlerin farklı düzeylerinin bir araya gelerek oluşturduğu 22 adet kart ile kart sayısı azaltılmış uygulama yapılmaktadır (Arslan, 2016, s. 311; Yiğit ve Çevik, 2011, s.108). 
Tablo 9: Kombinasyon (Kart) Örneği

\begin{tabular}{|l|c|}
\hline Tercih Sırası & 1 Yil \\
\hline Yatırım kârlılı̆̆ & Mevcut süreden daha kısa \\
\hline Yolculuk süresi & Konfor önceliksiz \\
\hline Konfor & Mevcuttan fazla \\
\hline Emisyon & Az \\
\hline Mekânsal tüketim & Düşük \\
\hline Rant & Çok \\
\hline Çevresel kirlilik & \\
\hline KART NO 1 & \\
\hline
\end{tabular}

Çalışma kapsamında sıralamaya dayalı konjoint uygulaması yapılarak konjoint uygulamasının yapıldığı uzmanlardan kartların en çok tercih edilenden en az tercih edilene doğru sıralaması istenmektedir. Çalışma için yerel yönetim, kamu ve akademisyen olmak üzere 3 farklı alandan 34 uzman ile uygulama yapılmıştır.

Konjoint analizi yapılırken SPSS programın syntax modülünden yararlanılmaktadır. Syntax modülünden yararlanmak için ölçüt düzeyleri ve tercih ilişkileri arasında kurgular yapılması gerekmektedir. Tercih sıralaması açısından doğrudan artış beklenen faktör "linear more", doğrusal azalma beklenen faktör için "linear less" ve düzeyleri arasında kategoriye dayalı ilişki olan faktörler ise "discrete" olarak tanımlanmaktadır.

34 ayrı uzmanın her birinden ayrı ayrı elde edilen sıralamalar doğrultusunda kart ve tercih sıralamalarına ilişkin bilgiler SPSS programının arayüzüne girilmektedir.

CONJOINT PLAN = 'D:Icardss.sav'

$/$ DATA ='D: IPref.sav'

$/$ SUBJECT $=$ ID

/SEQUENCE=PREF1 TO PREF22

/FACTORS=yatirim (LINEAR LESS)

yolculuk_suresi(LINEAR LESS) konfor(LINEAR LESS) emisyon(LINEAR LESS) mekansa_tuketim(LINEAR LESS) rant(LINEAR MORE) cevresel_kirlilik(LINEAR LESS)

$/ \mathrm{PLOT}=\mathrm{ALL}$

$/$ PRINT $=$ SIMULATION ALL.

Kent içi raylı sistemlerin özelliklerinin konjoint analizinde yatırım ölçütü olarak değerlendirilmesi sonucunda çalışmada uzman görüşleri ile birlikte birtakım bulgulara ulaşılmaktadır. Bulgular kapsamında her bir ölçütün ve ölçüt düzeyinin uzmanlarca yatırım kararının alınmasında farklı bir önemde olduğu anlaşılmaktadır. Çalışma kapsamında değerlendirilen 7 ölçütün önem değerlerinin konjoint analizi sonucunda Tablo 10'da olduğu gibi hesaplanmaktadır. 
Tablo 10: Ölçütlerin Önem Değerleri

\begin{tabular}{|c|c|}
\hline \multicolumn{2}{|c|}{ Önem Değerleri (\%) } \\
\hline Yatırım Karlıı̆̆1 & 22,503 \\
\hline Yolculuk süresi & 32,079 \\
\hline Konfor & 11,187 \\
\hline Emisyon & 7,071 \\
\hline Mekânsal Tüketim & 12,612 \\
\hline Rant & 4,053 \\
\hline Çevresel kirlilik & 10,495 \\
\hline
\end{tabular}

Konjoint analizi sonucunda ortaya çıkan diğer sonuçlar ise incelenen ölçütlerin ve ölçüt düzeylerinin faydalarına yönelik katsayılar ve standart hata değerleridir. (Bkz. Tablo 11)

Tablo 11: Ölçüt ve Düzeyler

\begin{tabular}{|c|c|c|c|}
\hline \multicolumn{2}{|r|}{ Ölçüt ve Düzeyler } & Fayda Tahmini & Std. Hata \\
\hline \multirow{3}{*}{ Yatırım Karlılığ1 } & $1 Y_{11}$ & $-2,237$ & 085 \\
\hline & $5 Y_{11}$ & $-4,474$ &, 171 \\
\hline & $10 Y_{11}$ & $-6,711$ & 256 \\
\hline \multirow{3}{*}{ Yolculuk süresi } & Mevcut süreden daha kısa & $-3,490$ & ,092 \\
\hline & Mevcut süre değişmiyor & $-6,980$ & , 184 \\
\hline & Mevcut süreden daha uzun & $-10,471$ & ,275 \\
\hline \multirow{2}{*}{ Konfor } & Konfor öncelikli & $-2,445$ & , 148 \\
\hline & Konfor önceliksiz & $-4,891$ & ,296 \\
\hline \multirow{2}{*}{ Emisyon } & Mevcuttan az & $-1,357$ & 130 \\
\hline & Mevcuttan fazla & $-2,714$ & ,260 \\
\hline \multirow{3}{*}{$\begin{array}{l}\text { Mekânsal } \\
\text { Tüketim }\end{array}$} & $\mathrm{Az}$ & $-1,369$ & ,087 \\
\hline & Orta & $-2,738$ &, 175 \\
\hline & Çok & $-4,107$ & ,262 \\
\hline \multirow{3}{*}{ Rant } & Düşük &, 042 & 107 \\
\hline & Orta &, 085 &, 213 \\
\hline & Yüksek &, 127 &, 320 \\
\hline \multirow{3}{*}{ Çevresel kirlilik } & $\mathrm{Az}$ & $-1,061$ & ,089 \\
\hline & Orta & $-2,122$ &, 178 \\
\hline & Çok & $-3,184$ & ,267 \\
\hline \multicolumn{2}{|l|}{ Sabit } & 30,963 &, 537 \\
\hline
\end{tabular}


Tablo 11'da görüldüğü üzere her bir ölçüt düzeyinin niteliğine göre farklı değerde sahip olduğu bir fayda tahmini bulunmaktadır. Fayda tahmini konjoint analizinin uygulaması yapılan uzmanların eğiliminin sayısal ifadesidir. Yatırım karlılığı konusunda fayda, yatırımın kendisini daha kısa sürede ödediği durumlarda görülmektedir. Yolculuk süresi konusunda fayda daha kısa sürede gerçekleşen yolculuklarda görülmektedir. Konfor konusunda fayda, konfor öncelikli sistemlerde görülmektedir. Emisyon konusundaki fayda ise emisyonun mevcut durumdan daha az olduğu koşullarda görülmektedir. Mekânsal tüketim açısından yapılacak yatırımın az mekan tüketmesi gerektiği yönünde bir eğilim bulunmaktadır. Rant ölçütü açısından ise uzmanlar yapılacak bir yatırımın yüksek rant oluşturduğu durumlarda faydanın daha fazla olduğu eğilimindedir. Çevresel kirlilik açısından ise fayda az çevresel kirlilik oluşturan koşullarda yer almaktadır.

Ölçütler açısından konjoint analizi yeniden yorumlanırsa uzmanların görüşüne göre orta ölçekli bir kentte yapılacak kent içi raylı sistem söz konusu olduğunda yapılacak yatırımın sırası ile yolculuk süresi konusunda daha sonra yatırım maliyeti, mekânsal tüketim, konfor, çevresel kirlilik, emisyon, rant konularında faydalar sağlaması gerektiği hesaplanmaktadır.

Konjoint analizi sonucunda elde edilen değerlerden aynı zamanda model kurulmasında yararlanılmaktadır. Ancak model sonuçlarının doğru olması için yapılan çalışmanın da doğruluğunun test edilmesi gerekmektedir. Bundan dolayı çalışma kapsamında korelasyon ile konjoint analizinin temsil gücü değerlendirilmektedir. (Bkz. Tablo 12)

Tablo 12: Korelasyon Tablosu

\begin{tabular}{|l|c|c|}
\hline & Değer & Sig. \\
\hline Pearson's R &, 998 &, 000 \\
\hline Kendall's tau &, 961 &, 000 \\
\hline Kendall's tau for Holdouts &, 667 &, 087 \\
\hline
\end{tabular}

Tablodan görüldüğü üzere konjoint analizinin Pearson's R ve Kendall's Tau değeri yüksek olduğundan yapılan analizin gerçeği temsil seviyesinin üst düzeyde olduğu görülebilmektedir (Eriş Uçurum, 2018, s. $58)$.

Fayda tahminleri incelendiğinde çeşitli negatif değerlerin olduğu görülmektedir. Negatif değerler uzmanların o konuda ilgili düzeyin dikkat çekmesine ilişkin değil hangi ölçütün ne daha fazla sayıda tercih edildiğine yönelik fikir oluşmasını sağlamaktadır. Fayda tahminleri açısından bir yorum yapılacak olursa uzmanlar kendilerine verilen 22 kombinasyon içerisinde yatırım karlılığı açısından daha uzun süreyi işaret eden kombinasyonları, sıralamada sonlara yakınlaştırmıştır anlamı çıkmaktadır.

Erzincan kenti kapsamında kent içi raylı sistem yatırımları ulaşım ana planı kapsamında oluşturulan 4 senaryonun 2'sinde yer almaktadır. Bu senaryolar şu şekildedir.

1- Mevcut durum senaryosu

2- Lastik tekerlekli gelişim senaryosu

3- Raylı sistem gelişim senaryosu

4- Rayl1 sistem alternatif gelişim senaryosu

Söz konusu senaryolar ulaşım ana planı kapsamında çok ölçütlü değerlendirme çalışmalarının önemli bir bileşenidir. UAP çok ölçütlü değerlendirme çalışmasında senaryoların çeşitli ölçütler ile değerlendirildiği görülmektedir. Değerlendirmede kullanılan ölçütler bu çalışmada ele alınan konjoint analizinin ölçütleri ile benzerlik gösterdiğinden konjoint analiz modeli ile orta ölçekli kentler düşünülerek yapılan konjoint analizi değerlerinden yararlanılarak Erzincan kenti için en yararlı kent içi raylı sistem değerlendirilebilmektedir. Erzincan ulaşım ana planı ölçütleri tabloda olduğu gibidir. 
Tablo 13: Erzincan Ulaşım Ana Planı Ölçüt Çizelgesi

\begin{tabular}{|c|l|l|}
\hline \multirow{2}{*}{ Ana Ölçütler } & \multicolumn{1}{|c|}{ Alt Ölçütler } & \multicolumn{1}{c|}{ Tanım } \\
\hline \multirow{2}{*}{ Ekonomik } & Yolculuk maliyeti & İşletme için, bir kişinin yarattı̆̆ yolculuğun maliyeti \\
\cline { 2 - 3 } Çevresel & Yatırım maliyeti & İşletmenin ulaşım türlerine yönelik yatırım miktarı \\
\hline \multirow{2}{*}{ Sosyal } & Hava kirliliği & Ulaşı̈ı türlerinin yarattı̆̆ı̈ emisyon değeri \\
\cline { 2 - 3 } & Enerirliliği & Ulaşım türlerinin yarattığı desibel değeri \\
\hline & Erişim süresi & Ulaşım türlerinin enerji tüketimi $(\mathrm{kcal} /$ yolcu) \\
\hline
\end{tabular}

Erzincan ulaşım ana planı kapsamında gerçekleştirilen çok ölçütlü değerlendirme çalışmasında yolculuk maliyeti, yatırım maliyeti, hava kirliliği, gürültü kirliliği, enerji kirliliği ve erişim süresi konularına ilişkin standardize edilmiş değerler bulunmaktadır. Ulaşım ana planı çok ölçütlü değerlendirme çalışmasında ve konjoint analizinde eşleşen değerler, hava kirliliği - emisyon, çevresel kirlilik - gürültü kirliliği, erişim süresi - yolculuk süresi şeklindedir.

Ölçütler negatif kavramları ifade ettiğinden dolayı en fazla negatif fayda değerine sahip senaryo 1 değerini alacak şekilde en az negatif fayda değerine sahip senaryo daha düşük değeri alacak şekilde standardizasyon tablosu şu şekildedir.

Tablo 14: Senaryo Standartları

\begin{tabular}{|c|c|c|c|c|}
\hline & $\begin{array}{c}\text { Mevcut durum } \\
\text { senaryosu }\end{array}$ & $\begin{array}{c}\text { Lastik tekerlekli } \\
\text { gelişim senaryosu }\end{array}$ & $\begin{array}{c}\text { Raylı sistem gelişim } \\
\text { senaryosu }\end{array}$ & $\begin{array}{c}\text { Raylı sistem alternatif } \\
\text { gelişim senaryosu }\end{array}$ \\
\hline Hava kirliliği & 0,84 & 1 & 0,71 & 0,78 \\
\hline Gürültü & 0,85 & 1 & 0,71 & 0,86 \\
\hline Erişim süresi & 1 & 0,9 & 0,73 & 0,88 \\
\hline
\end{tabular}

$\mathrm{Bu}$ değerlerin oluşturduğu faydalar konjoint analizinde ilgili karşıllı̆̆a denk geldiğinde konjoint modeli kurularak hangi senaryonun ne kadar fayda ürettiğgi görülebilmektedir. Buradaki değerleri konjoint modelinde kullanabilmek için standardizasyon modelinin konjoint analizi kapsamında ortaya konan fayda analizine dönüştürülmesine gerek duyulmaktadır. Dönüşüm için Tablo 11'dan yararlandığımızda Tablo 15'teki sonuç karşımıza çıkmaktadır.

Tablo 15: Standardizasyonların Fayda Tahminine Dönüşümü

\begin{tabular}{|l|c|c|c|c|}
\hline & $\begin{array}{c}\text { Mevcut } \\
\text { Durum } \\
\text { senaryosu }\end{array}$ & $\begin{array}{c}\text { Lastik tekerlekli } \\
\text { gelişim senaryosu }\end{array}$ & $\begin{array}{c}\text { Raylı sistem gelişim } \\
\text { senaryosu }\end{array}$ & $\begin{array}{c}\text { Raylı sistem alternatif } \\
\text { gelişim senaryosu }\end{array}$ \\
\hline Hava kirliliği & $-1,357$ & $-2,714$ & $-1,357$ & $-1,357$ \\
\hline Gürültü & $-2,122$ & $-3,184$ & $-1,061$ & $-2,122$ \\
\hline Erişim süresi & $-10,471$ & $-6,98$ & $-3,49$ & $-6,98$ \\
\hline
\end{tabular}


Senaryoların fayda tahminlerinden yararlanılarak konjoint analiz modeli ile senaryoların üreteceği toplam fayda hesaplanmaktadır.

Konjoint analiz modeli için denklem şu şekildedir.

$\mathrm{D}_{\mathrm{MFF}}$ : Sabit + [1.Faktör Düzeyi*(1.Faktör İlişki Katsayıs1 (Ör: Yatırım Maliyeti))] + [2.Faktör Düzeyi*(2.Faktör İlişski Katsayısı (Ör: Emisyon))] + [n. Faktör Düzeyi*(n.Faktör İlişki Katsayısı]

Senaryoların fayda tahmin değerleri ile hesap yapıldığında Bkz. Tablo 16

Tablo 16: Konjoint Analiz Modelinin Sonuçları

\begin{tabular}{|l|c|c|c|c|c|}
\hline & $\begin{array}{c}\text { Mevcut } \\
\text { durum } \\
\text { senaryosu }\end{array}$ & $\begin{array}{c}\text { Lastik } \\
\text { tekerlekli } \\
\text { gelişim } \\
\text { senaryosu }\end{array}$ & $\begin{array}{c}\text { Raylı sistem } \\
\text { gelişim } \\
\text { senaryosu }\end{array}$ & $\begin{array}{c}\text { Raylı sistem } \\
\text { alternatif } \\
\text { gelişim } \\
\text { senaryosu }\end{array}$ & $\begin{array}{c}\text { İlişki katsayıs1 } \\
\text { (B) }\end{array}$ \\
\hline Hava kirliliği & $-1,357$ & $-2,714$ & $-1,357$ & $-1,357$ & $-1,357$ \\
\hline Gürültü & $-2,122$ & $-3,184$ & $-1,061$ & $-2,122$ & $-1,061$ \\
\hline Erişim süresi & $-10,471$ & $-6,98$ & $-3,49$ & $-6,98$ & $-3,49$ \\
\hline Sabit & 31 & 31 & 31 & 31 & - \\
\hline Toplam & 71,636681 & 62,421322 & 46,14727 & 59,453091 & - \\
\hline
\end{tabular}

Tablo 16'da görüldüğü üzere raylı sistem gelişim senaryosunun yaklaşık 46 değeri ile en fazla faydanın yer aldığı senaryo olarak değerlendirilebilmesi söz konusu olmaktadır.

\section{SONUÇLAR}

Kentler, yapılı alanların göreceli olarak yoğunlukta bulunduğu alanlardır. Bu alanlarda yaşayan insan topluluklarının kendi yaşam alışkanlıklarına göre çeşitli ihtiyaçları bulunmaktadır. Bu ihtiyaçlardan birisi insanların bir noktadan bir diğerine gitme isteğini ifade eden ulaşım kavramıdır.

Ulaşım kavramında yaşanan taleplere karşı cevaplar teknolojiye bağlı olarak günümüzde çeşitli araçların elverdiği imkânlar ile birlikte üretilmektedir. Taleplere cevap üretmek, üretilen cevabın türüne bağlı olarak kaynak tüketimini gerektirmektedir. Günümüzde yatırımlar aracılığıyla kentsel alanlardaki ulaşım problemleri çözülmektedir. Problem çözmede etkin olarak kullanılan araçlardan birisi de kent içi raylı sistemlerdir. Kent içi raylı sistemler ekonomik, sosyal ve çevresel açıdan faydalar içermesine rağmen yatırım değerlendirme çalışmalarında sadece ekonomik ölçütlerin etkili olduğu açılardan ele alınarak yatırım kararları alınmaktadır. Türkiye gibi her kenti farklı dinamiklere sahip olan ülkelerde kent içi raylı sistemlerin yaygınlaşmasında kentin özellikleri ve ihtiyaçlarına yönelik olmadan sadece ekonomik ölçütlere bağlı olarak yatırım kararı alınması elde edilecek sosyal ve çevresel faydaların önüne geçilmesini sağlamaktadır.

Bu çalışma ile birlikte kent içi raylı sistemler kamusal bir hizmet olarak ele alınmakta ve kent içi raylı sistem yatırımları için ölçüt ve ölçüt düzeylerinden yararlanılarak modern gerekliliklere yönelik bir yatırım ölçüt havuzu geliştirilmektedir. Yatırım ölçütü geliştirilmesinde kullanılan konjoint yönteminden yararlanılarak orta ölçekli bir kent için ekonomik, sosyal ve çevresel olarak farklı nitelikteki ölçütlerin hangi değerde ne kadar önemli olduğu tespit edilmektedir.

Çalışmanın ortaya koyduğu sonuçlara orta ölçekli bir kentte raylı sistem yatırımı yapıldığında yapılacak yatırımın öncelikle yolculuk süresinde daha sonra yatırım karlılığı konusunda ve sırayla mekânsal tüketim, çevresel kirlilik, konfor, emisyon ve rant açısından fayda sağlaması gerektiği tespit edilmektedir. 
Çalışmanın konjoint analizinden yararlanarak ortaya koyduğu modelde Erzincan kent içi raylı sistem için bir uygulama bulunmaktadır. Uygulamada Erzincan ulaşım ana planı kapsamında ortaya konan 4 senaryonun verisinden yararlanarak konjoint analiz modeli ile hesap yapıldığında kent içi raylı sistem senaryosu içeren senaryoların en fazla faydayı üreten senaryolar olduğu görülmektedir.

Çalışma, en genel kapsamda kent içi raylı sistem yatırım kararlarının alınmasında sadece ekonomik ölçütlere dayalı kararlar alınmasının yanında sosyal ve çevresel kazanımların da elde edilmesini sağlayabileceği modern fizibilite yapılarının olmasını gerektiğini savunmaktadır. Çalışmaya göre bir ülkede yapılacak raylı sistem yatırımı kararının alınmasında bütün kentler için tek bir ölçütün etkili olması kazanılacak diğer faydaları elde etmenin önüne geçeceği gibi kalkınmanın da önünde de bir engel oluşturmaktadır.

Bilgilendirme / Acknowledgement: Bu çalışma, Dr. Öğr. Üyesi Hayri ULVİ danışmanlığında Furkan AKDEMİR tarafindan Gazi Üniversitesi Fen Bilimler Enstitüsü Şehir ve Bölge Planlama Anabilim Dalında 2019 yılında tamamlanan "Raylı Ulaşım Fizibilitelerinde Yeni Yaklaşımlar ve Konjoint Analizinin Erzincan Kentinde Uygulanması " konulu yüksek lisans tezine dayalı hazırlanmış olup Gazi Üniversitesi KUTEM ile Erzincan Belediyesi arasında ortak hizmet projesi şeklinde yürütülmüş olan Erzincan Raylı Sistem Fizibilite Etüdü ve Avan Projesi bilgilerinden faydalanılmıştır.

\section{KAYNAKÇA}

Aktan, Esin. Kent İçi Ulaşımda Yeni Teknolojiler Kent Biçimine Olası Yansıması. 1 Nisan 2019 tarihinde http://www.imo.org.tr/resimler/ekutuphane/pdf/3193.pdf adresinden erişildi.

Aktaş, S., Akkuş, Ö., Osmanoğlu, S. (2012). Çok düzeyli bağımlı değişken modellemesinde koşullu lojit ve konjoint analizlerinin performansları üzerine uygulamalı bir çalışma. İstanbul Ticaret Üniversitesi Fen Bilimleri Dergisi, 11(21), 25-40.

Arslan, H. (2016). Konjoint analizi ile en uygun yatırım aracının belirlenmesi. Ístanbul Ticaret Üniversitesi Sosyal Bilimler Dergisi, 15(29), 305-317.

Aydın, N., ve Yalçın, E. (2016). Seçime dayalı konjoint analizi ve bir uygulama. Dumlupınar Üniversitesi Sosyal Bilimler Dergisi, (50), 26-48.

Babalik-Sutcliffe, E. (2002). Urban rail systems: analysis of the factors behind success. Transport Reviews, 22(4), 415-447.

Candemir, I., Tanyel, S., Hizlı raylı sistemlerin yolcu taşıma kapasite hesaplamaları ve Türkiye'deki benzer sistemlerin birbirleriyle karşılaş̧tırlması. 11 Kasım 2018 tarihinde http://www.imo.org.tr/resimler/ekutuphane/pdf/3205.pdf adresinden erişildi.

Cengiz, M., \& Girginer, N. (2012). Konjoint analizi ile tüketici tercihlerinin belirlenmesi: Buzdolab1 örneği. Eskişehir Osmangazi Üniversitesi İktisadi ve İdari Bilimler Dergisi, 7(1), 269-290.

Cirit, F. (2014). Sürdürülebilir kentiçi ulaşım politikaları ve toplu taşıma sistemlerinin karşılaş̧tıılması. Uzmanlık Tezi, Ankara: T.C. Kalkınma Bakanlığı, 2-5.

Düzkaya, H., Akdemir, F., Hayri, Ulvi., Orman, A., \& Sıvat, S. Türkiye'de orta büyüklükteki kentlerde raylı sistem uygulamaları: Erzincan cadde tramvayı örneği. El-Cezeri Journal of Science and Engineering, 5(2), 403-415.

Eriş Uçurum, Ü. (Mayıs 2018), İşseçimlerinde KOBI'lerin tercih edilmelerini sağlayacak stratejilerin konjoint analizi ile belirlenmesi. Yayımlanmamış yüksek lisans tezi, İstanbul Teknik Üniversitesi, Fen Bilimleri Enstitüsü, İstanbul. 
Gürbüz, H., \& Kaygısız, Z. (2004). Konjoint analizi ve ulaşım sektör pazarı üzerine bir çalışma. Süleyman Demirel Üniversitesi İktisadi ve İdari Bilimler Fakültesi Dergisi, 9(1), 139148.

Jain, S., Aggarwal, P., Kumar, P., Singhal, S. and Sharma, P. (2014). Identifying public preferences using multi-criteria decision making for assessing the shift of urban commuters from private to public transport: A case study of Delhi. Transportation Research Part F: Traffic Psychology and Behaviour, 24, 60-70.

Jayaraman, K., Suan, J. C. S., \& Lin, S. K. (2011). Robust models for the utilization of public bus transport services in Malaysia. African Journal of Business Management, 5(26), 10586-10600.

Jianrong, L., Wei, D., \& Zhang, B. (2011). Conjoint analysis based transit service quality research. Journal of transportation systems engineering and information technology, 11(4), 97102.

Kılıçaslan, H. (2015). Belediyelerin raylı ulaşım hizmetlerinin yaygınlaştırılması: Bursa büyükşehir belediyesi örneği* / Expanding the rail transport services of municipalities: The case of Bursa metropolitan municipality. Yönetim ve Ekonomi, 22(2), 451

Kofteci, S., Ergun, M., \& Ay, H. S. (2010). Modeling freight transportation preferences: Conjoint analysis for Turkish Region. Scientific Research and Essays, 5(15), 2016-2021.

KUTEM a (2017), Erzincan belediyesi ulaşım ana planı. 2, 137-186.,Ankara: Gazi Üniversitesi Kent İçi Ulaşım Teknolojileri Erişebilirlik Uygulama ve Araştırma Merkezi (KUTEM).

KUTEM b (2017). Erzincan belediyesi raylı sistem fizibilite etüdü ve avan projeleri fizibilite raporu. Ankara: Gazi Üniversitesi Kent İçi Ulaşım Teknolojileri Erişebilirlik Uygulama ve Araştırma Merkezi (KUTEM), 1-70.

Muraleetharan, T., Adachi, T., Uchida, K. E., Hagiwara, T., \& Kagaya, S. (2003). A study on evaluation of pedestrian level of service along sidewalks and at intersections using conjoint analysis. In Annual Meeting of Japanese Society of Civil Engineers (JSCE) Infrastructure Planning, Toyohashi, Japan.

Newman, P. (2012). Why do we need a good public transport system. Research Paper, Curtin University Sustainability Policy (CUSP) Institute.

Öğüt, K. S., \& Evren, G. (2006). Türkiye'de kentsel raylı sistemlerin gerekliliği ve uygulamada dikkat edilecek konular. Uluslararası Demiryolu Sempozyumu, Türkiye, 1-10.

Önder, H.G, Kaplan, H. (2017) Ankara'da park et-devam et sisteminin modellenmesi ile yolculuk değişimine bağlı emisyon azaltımının ölçülmesi. Gazi Üniversitesi Fen Bilimleri Dergisi Part C: Tasarım ve Teknoloji, 5(1), 139-152.

Önder, M. (2016). Ankaray hafif raylı taşıtlarında oturma düzeninin yeniden tasarlanması. Gazi Mühendislik Bilimleri Dergisi, 1(1), 21 - 40.

Önder, H.G, Akdemir, F. (2019) Türkiye'deki Kentiçi Raylı Toplu Taşıma Sistemlerinin Ulaşım Ana Planları Bağlamında Değerlendirilmesi. Demiryolu Mühendisliği, (10), 23-37. 
Özden, R. (2012). Karşılaştırmalı standart belirleme yöntemi ile ülkemizdeki hafif raylı sistemlerin karşılaştırılması. Yayımlanmamış yüksek lisans tezi, Dumlupınar Üniversitesi Fen Bilimleri Enstitüsü, Afyon.

Saraçlı, S., ve Şıklar, E. (2005). Bireysel emeklilik şirketlerinin tercihinde etkili olan faktörlerin konjoint analizi ile incelenmesi. Examining the individual retirement account with conjoint analysis. Sosyal Bilimler Dergisi, 2, 1-12

Segal, R. (1995). Forecasting the market for electric vehicles in California using conjoint analysis. The Energy Journal, 89-111.

Soykan, Y. (2009). Endüstriyel satın alma kararlarında konjoint analizi ve bir uygulama. Akademik Bakış, $16,1-18$.

Sönmez, H. (2006). Müşteri tercihleri için konjoint analizi uygulaması: Ev bilgisayarı nasıl seçilir. Sosyal Bilimler Dergisi, 2, 185 - 196.

Suh, Y. K., \& Gartner, W. C. (2004). Preferences and trip expenditures-a conjoint analysis of visitors to Seoul, Korea. Tourism Management, 25(1), 127-137.

Şahin, S. Z. (2012). Kent planlama süreci ile kentsel altyapı yatırımlarının ilişkisi: Ankara örneği. İnşaat Mühendisleri Odası 6. Kentsel Altyapı Sempozyumu, Antalya.

Tanış, M., \& Öğüt, K. M. (2007). Orta ölçekli kentler için toplu taşıma seçeneklerinin teknik ve mali karş1laştırması. 5. Kentsel Altyapı Ulusal Sempozyumu, 2-3.

Thompson, D. J., \& Jones, C. J. C. (2000). A review of the modelling of wheel/rail noise generation. Journal of Sound and Vibration, 231(3), 519-536.

Turanl1, M., Cengiz, D. T., Mert, I. (2013). Konjoint analizi ile gazete tercihlerini etkileyen faktörlerin belirlenmesi. Ekonometri ve Istatistik e-Dergisi, (19), 1-26.

Ulaştırma, Denizcilik ve Haberleşme Bakanlığı Demiryolları Limanlar ve Hava Meydanları İnşaatı Genel Müdürlüğü. (2014). DLH ulaşım ve fizibilite etüdü teknik şartnamesi. Ankara, 1-35.

Üzmez, U. (2012). Türkiye'de orta ölçekli kentsel alanlar sorununa çözüm arayışları: Zonguldak örneği. Íktisadi ve İdari Bilimler Fakültesi Dergisi, 14(2), 1-32.

Yaman, H. T., \& Dalkıç, G. (2019). Evaluation of the pricing preferences and value of time for High Speed Rail (HSR) users in Turkey. Journal of the Faculty of Engineering and Architecture of Gazi University, 34(1), 255-273.

Yavuz, S., \& Çemrek, F. (2013). Konjoint analizi ile sağlık çalı̧̧anlarının konut tercihlerinin belirlenmesi. Atatürk Üniversitesi Sosyal Bilimler Enstitüsü Dergisi, 17(2), 379-396.

Yiğit, A. M., \& Çevik, O. (2011). Konjoint analizi ile ofis mobilyası tüketicilerinin tercihlerinin belirlenmesi. KMÜ Sosyal ve Ekonomik Araştırmalar Dergisi, 13(20), 105-110.

Wardman, M. (2014). Valuing convenience in public transport: Roundtable summary and conclusions. International Transport Forum Discussion Paper. 
Wooliscroft, B., \& Ganglmair-Wooliscroft, A. (2014). Improving conditions for potential New Zealand cyclists: An application of conjoint analysis. Transportation research part A: policy and practice, 69, 11-19.

Zak, J. (2011). The methodology of multiple criteria decision making/aiding in public transportation. Journal of Advanced Transportation, 45(1), 1-20. 